\title{
Evaluation of Anti-Cancer Activity of Gryllus bimaculatus Water Extract on Non-Small Cancer Lung Cell via Apoptosis
}

\author{
Hyun Jung Lim* and Eui-Hong Byun \\ Department of Food Science and Technology, Kongju National University, Chungnam 32439, Korea
}

\begin{abstract}
Gryllus bimaculatus, traditionally used in oriental medicine, demonstrates functional and pharmacological potential through demonstrating immunomodulatory, hepato-protective properties, anti-inflammatory, antioxidant, and neuroprotective effects. In this study, we examined the effect of G. bimaculatus on cell proliferation and apoptosis in lung cancer cells. This is the first study to examine the anti-cancer effects of G. bimaculatus extracts on non-small cell lung cancer. Frozen G. bimaculatus was obtained, homogenized, and dissolved in distilled water. Using a freeze dryer, samples were concentrated until almost all the water was removed, and extracts were diluted in solutions of phosphate buffered saline. Anti-cancer effects of extracts on human non-small cancer lung cells were estimated based on cell cytotoxicity, western blot, and flow cytometry, using lipopolysaccharides as a positive control. H460 and A549 human non-small cell cancer lung cells were treated with G. bimaculatus water extracts of various concentrations, with lipopolysaccharide used as a positive control. The results showed that treatment with the extract for 24 or $48 \mathrm{~h}$ inhibited H460 proliferation, demonstrated by reduced cell numbers with morphological changes. Furthermore, flow cytometry analysis demonstrated that the extracts induced cell death on H460. However, extracts did not show cytotoxic effects on A549 cells. In conclusion, the extract induced apoptosis of lung cancer cells, possibly via caspase, Bcl-2 family signaling pathways. Therefore, G. bimaculatus water extracts are safe and efficient natural materials that may have great potential in the treatment of lung cancer.
\end{abstract}

Keywords: anti-cancer effect, apoptosis, edible insect, Gryllus bimaculatus, lung cancer

\section{INTRODUCTION}

Edible insects are commonly consumed worldwide due to their size, availability, and nutritional benefit. As an alternative source of animal proteins, edible insects can help solve food shortage problems (Rumpold and Schlüter, 2015; van Huis et al., 2015). Edible crickets have been approved as a food ingredient by the Korea Ministry of Food and Drug Safety because of their high contents of chitin, amino acids, and unsaturated fatty acids (Lee et al., 2016).

Gryllus bimaculatus is a species of cricket in the subfamily Gryllinae. It is also known as the African and Mediterranean field cricket or as the two-spotted cricket, and is one of the most abundant cricket species, inhabiting the tropical and subtropical regions of Asia, Africa, and Europe (Lee and Kwon, 2013). G. bimaculatus can be discriminated from other Gryllus species by two dot-like marks on the base of its wings. G. bimaculatus can be easily bread in laboratories where it is widely used in insect research, and is mass produced as feed for insectivorous animals in confined facilities such as zoos (Mito and Noji, 2008). G. bimaculatus are easy to breed and raise since they do not require prolonged exposure to cold to complete their life cycle. G. bimaculatus has a good nutritional content of fat, protein, polyunsaturated fatty acid, mineral, and fiber, and is high in essential amino acids including lysine, leucine, valine, and isoleucine (Belluco et al., 2013). G. bimaculatus also contains high concentrations of fatty acids especially unsaturated fatty acids $(68.6 \%)$, such as linoleic and oleic acid.

G. bimaculatus has traditionally been used in oriental medicine. Efforts have been made to investigate the functional and pharmacological potential of G. bimaculatus, including its immunomodulatory (Seo et al., 2004), hepato-protective (Im et al., 2018), anti-diabetic (Cho et al., 2019), anti-inflammatory (Ahn et al., 2014; Hwang et al., 2019), antioxidant (Jang and Kim, 2021), and neuropro-

Received 31 August 2021; Revised 18 October 2021; Accepted 3 November 2021; Published online 31 December 2021

Correspondence to Eui-Hong Byun , Tel: +82-41-330-1481, E-mail: ehbyun80@kongju.ac.kr

*Current Address: Institute of Fisheries Sciences, Pukyong National University, Busan 46041, Department of Liberal Arts, Gyeongbuk Provincial College, Gyeongbuk 36830, Korea

Author information: Hyun Jung Lim (Instructor), Eui-Hong Byun (Professor)

Copyright (๑) 2021 by The Korean Society of Food Science and Nutrition.

() This is an Open Access article distributed under the terms of the Creative Commons Attribution Non-Commercial License (http://creativecommons.org/licenses/by-nc/4.0) which permits unrestricted non-commercial use, distribution, and reproduction in any medium, provided the original work is properly cited. 
tective effects (Boonsin et al., 2018), and its protective effect on the skin (Jeong et al., 2020). It is commonly recognized that the pathogenesis of human cancer is correlated with accumulation of multiple abnormalities over a long period of time.

Lung cancer is one of the serious types of cancer and is leading cause of cancer-related motility in both men and women. With an increasing number of smokers and environmental pollutants, the incidence of lung cancer has increased in recent years. Approximately 1.6 million people died from lung cancer in 2012, accounting for around $19 \%$ of all cancer deaths globally (Liu et al., 2017). Lung cancer motility rates exceed the sum of colon, breast, and prostate mortality rates (Siegel et al., 2016). Symptoms of lung cancer in the early stages are not always evident, and most patients with lung cancer are diagnosed in advanced stages, which often prevents effective treatment. Because lung cancer has a poor prognosis, over $85 \%$ of patients with lung cancer die from disease during the first 5 years (Panov, 2005). At present, the clinical treatment for lung cancer is mainly radiochemotherapy and surgery. However, effective treatment options are lacking. Therefore, it is important to develop novel treatments for lung cancer (Gu et al., 2018). However, research on the cytotoxic effect of lung cancer is limited, and there is limited research of G. bimaculatus in cancer. A foremost theory 'the inflammatory hypothesis' hypothesizes that inflammation is associated with the development and progression of cancer (Singh et al., 2019). Inflammation can cause immunosuppression, thereby providing tumors with growth factors such as fibroblast growth factor (FGF) and vascular endothelial growth factor (VEGF), which are mediators of angiogenesis and up-regulate oncogene expression (Carmeliet, 2005). Glycosaminoglycan (GAG), a component of G. bimaculatus, has anti-inflammatory effects (Hwang et al., 2019), such as the ability to reduce levels of inflammatory cytokines (Park and Han, 2021) including VEGF (Ahn et al., 2014). Therefore, GAG from G. bimaculatus may play a central role in modulating cell signaling through FGF and VEGF, thereby inhibiting anti-cancer effects. In this study, we examined the effect of $G$. bimaculatus water extracts on proliferation and apoptosis of lung cancer cells, and explored the possible mechanism of action. This is a first study to examine the anti-cancer effects of G. bimaculatus extract on non-small cell lung cancer cells.

\section{MATERIALS AND METHODS}

\section{Extraction of G. bimaculatus}

Frozen G. bimaculatus was obtained from SWorm (Cheonan, Korea), homogenized in a kitchen blender and dissolved in distilled water. Homogenized samples were so- nicated 3 times using a sonicator for $60 \mathrm{~min}$. The juice was filtered with Whatman paper, and the filtrate was evaporated at $40^{\circ} \mathrm{C}$ under reduced pressure until the solvent was removed. Using a freeze dryer, samples were concentrated until most of the water was removed, and samples were collected in empty tubes and stored at $-80^{\circ} \mathrm{C}$ in a defreezer. All extracts and substances were diluted in phosphate buffered saline solution before use.

\section{Cell lines and culture condition}

H460 and A549 cells, both human non-small cell lung carcinoma (NSCLC) cell lines, were purchased from the Korean cell line bank. H460 and A549 cells were maintained in Roswell Park Memorial Institute 1640 containing $10 \%$ fetal bovine serum and $1 \%$ antibiotics (penicillin/streptomycin) under humidified conditions of $37^{\circ} \mathrm{C}$ and $5 \% \mathrm{CO}_{2}$ in an incubator.

\section{Cell viability assays}

H460 and A549 cells were grown in 96-well plates at a density of $1 \times 10^{4}$ cells per well. Cells were allowed to attach for $24 \mathrm{~h}$, then were exposed to G. bimaculatus water extracts. At the end of the treatment period, $10 \mu \mathrm{L}$ of 3(4,5-dimethylthiazole-2-yl)-2,5-diphenyltetrazolium bromide (MTT) reagent $(5 \mathrm{mg} / \mathrm{mL})$ was added to each well. After $3 \mathrm{~h}$ incubation at $37^{\circ} \mathrm{C}$, supernatants were aspirated and formazan crystals were dissolved in $100 \mu \mathrm{L}$ of dimethyl sulfoxide at $37^{\circ} \mathrm{C}$ for 10 min with gentle agitation. The absorbance per well was measured at $540 \mathrm{~nm}$ using a microplate reader.

\section{Flow cytometry analysis}

H460 cells were plated in complete medium in 24-well plates at a density of $1.5 \times 10^{5}$ cells/well and treated with G. bimaculatus water extracts for 24 or $48 \mathrm{~h}$. Cells were harvested with trypsin, washed with phosphate buffered salines (PBS), and resuspended in binding buffer. Singlecell suspensions were incubated with annexin V-fluorescein isothiocyanate (FITC) for $30 \mathrm{~min}$ in the dark at room temperature. Propidium iodide (PI) was then added and cells were analyzed by flow cytometry (FACSort; Becton Dickinson, Rutherford, NJ, USA).

\section{Western blot analysis}

Cells were harvested and washed twice in PBS. For Western blot analysis, total proteins were prepared using PRO-PREP ${ }^{\mathrm{TM}}$ Protein Extraction Solution (iNtRON Biotechnology, Inc., Seongnam, Korea), and quantified using protein assay reagents. Extracted proteins were denatured by boiling in sample buffer at $100^{\circ} \mathrm{C}$ for $5 \mathrm{~min}$, and electrophoresed using $8 \%$ to $15 \%$ sodium dodecyl sulfatepolyacrylamide gel electrophoresis gels. Gels were transferred onto polyvinylidene fluoride membranes at $100 \mathrm{~V}$ for $60 \mathrm{~min}$ in transfer buffer and membranes were incu- 
bated with $5 \%$ non-fat dry milk in Tris-buffered saline (TBS) buffer at room temperature for $1 \mathrm{~h}$ to block nonspecific responses. Next, membranes were incubated with specific primary antibodies at $4^{\circ} \mathrm{C}$ overnight, washed for 1 $\mathrm{h}$ with TBS buffer, incubated with horseradish peroxidase-conjugated anti-mouse or anti-rabbit antibodies for $30 \mathrm{~min}$ at room temperature, and washed again with TBS buffer for $1 \mathrm{~h}$. Proteins were detected using enhanced chemiluminescence western blotting detection reagents.

\section{Statistical analysis}

Means and standard deviations were calculated using Graphpad Prism version 5 program (GraphPad Software Inc., San Diego, CA, USA). One-way analysis of variance (ANOVA) followed by Turkey's multiple comparison tests were used to compare differences between multiple groups. $P<0.05, P<0.01$, and $P<0.001$ were considered statistically significant.

\section{RESULTS AND DISCUSSION}

Effect of $G$. bimaculatus water extracts on cell viability of H460 cells

The H460 cell line was derived by Gazdar and associates in 1982 from the pleural fluid of a patient with large-cell lung cancer (Carney et al., 1985). H460 is a human largecell lung carcinoma line containing mutant K-Ras and wild-type p53 (Mitsudomi et al., 1991). Cells were treated with G. bimaculatus water extracts concentrations of $31.25,62.5,125,250,500$, and $1,000 \mu \mathrm{g} / \mathrm{mL}$ or lipopoly-

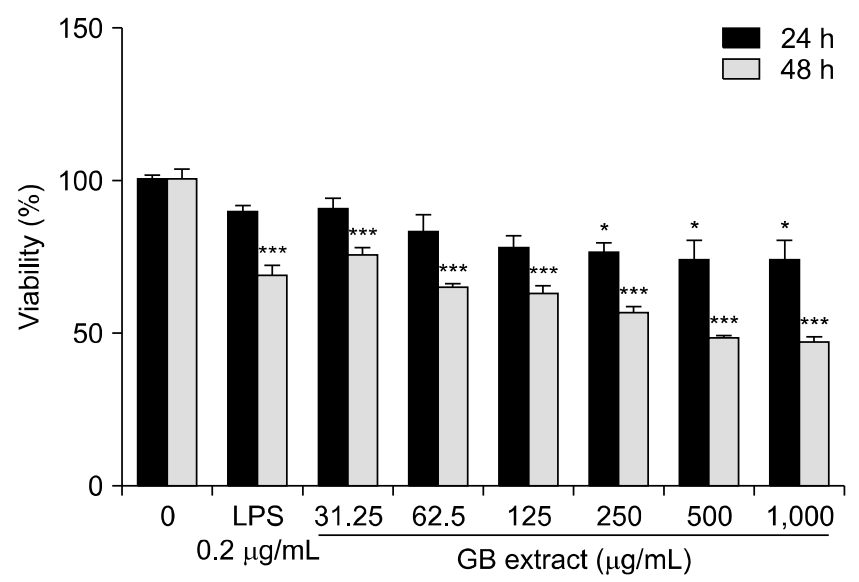

Fig. 1. Cytotoxic effects of Gryllus bimaculatus (GB) water extracts on $\mathrm{H} 460$ human lung cancer cells. Cells were treated with various concentrations of GB water extracts $(31.25,62.5,125$, 250,500 , and $1,000 \mu \mathrm{g} / \mathrm{mL}$ ) for 24 or $48 \mathrm{~h}$, and cell cytotoxicity was assessed using MTT assays. Results are expressed as mean $\pm S D(n=3)$. One-way analysis of variance (ANOVA) followed by Turkey's multiple comparison test was used to compare differences between multiple groups. Data were considered significantly different at ${ }^{*} P<0.05$ and ${ }^{* * *} P<0.001$ vs. non-treated controls. MTT, 3-(4,5-dimethylthiazole-2-yl)-2,5-diphenyltetrazolium bromide; LPS, lipopolysaccharide. saccharide (LPS) at $0.2 \mu \mathrm{g} / \mathrm{mL}$ as a positive control (Fig. 1). Recently, gold nanoparticles and LPS were shown to be cytotoxic and to induce apoptosis MCF-7 breast cancer cells (Sameen et al., 2020). Therefore, LPS is a potential anti-cancer agent with the ability to induce apoptosis (Morishima and Inagawa, 2016), and can decrease viability of adenocarcinoma and squamous esophageal carcinoma cells (Gonçalves et al., 2016), contributing to tumor death.

After treatment with G. bimaculatus extracts or LPS for 24 or $48 \mathrm{~h}$, cell proliferation was measured using MTT assays. Treatment with G. bimaculatus water extracts for 24 or $48 \mathrm{~h}$ inhibited $\mathrm{H} 460$ proliferation in a dose-dependent manner; inhibition was greater at $48 \mathrm{~h}$ than 24 h. Moreover, G. bimaculatus water extracts induced H460 cell apoptosis. Various concentrations of the extract reduced numbers of live $\mathrm{H} 460$ cell and induced morphology changes at $24 \mathrm{~h}$. Morphology changes included rounding, detachment and cell shrinking, which are distinct morphological characteristics related with apoptotic cells (data are not shown). Thus, G. bimaculatus water extracts demonstrated cytotoxicity in $\mathrm{H} 460$ cells and induced apoptosis.

\section{Effect of G. bimaculatus water extracts on cell viability of A549 cells}

A549 cells are adenocarcinomic human alveolar basal epithelial cells obtained through removing and culturing cancerous lung tissue from the explanted tumor of a 58year-old Caucasian male (Giard et al., 1973). A549 is a type II pulmonary epithelial cell model of lung cancer

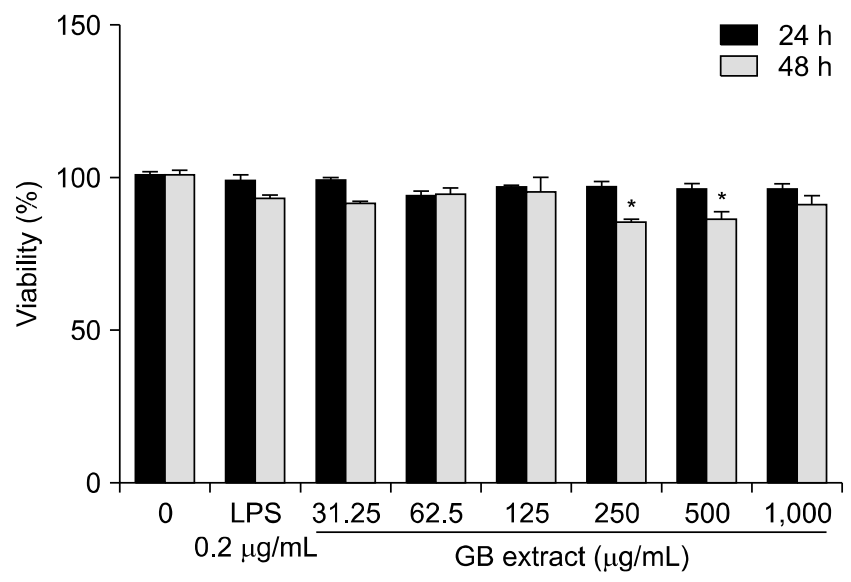

Fig. 2. Cytotoxic effect of Gryllus bimaculatus (GB) water extracts on A549 human lung cancer cells. Cells were treated with various concentrations of GB water extracts $(31.25,62.5,125$, 250,500 , and $1,000 \mu \mathrm{g} / \mathrm{mL}$ ) for 24 or $48 \mathrm{~h}$, and cell cytotoxicity was assessed using MTT assay. Results are expressed as mean $\pm S D(n=3)$. One-way analysis of variance (ANOVA) followed by Turkey's multiple comparison test was used to compare differences between multiple groups. Data were considered significantly different at ${ }^{*} P<0.05$ vs. non-treated controls. MTT, 3-(4,5-dimethylthiazole-2-yl)-2,5-diphenyltetrazolium bromide; LPS, lipopolysaccharide. 
and is widely used in the development of drug therapy for lung cancer (Foster et al., 1998). A549 cells were treated with G. bimaculatus water extracts at concentrations of $31.25,62.5,125,250,500$, and $1,000 \mu \mathrm{g} / \mathrm{mL}$ or LPS at $0.2 \mu \mathrm{g} / \mathrm{mL}$ as a positive control. The results showed that treatment with G. bimaculatus water extracts for 24 or $48 \mathrm{~h}$ did not inhibit A549 cell proliferation or induce apoptosis. Thus, G. bimaculatus water extract did not show a cytotoxicity event in A549 cells (Fig. 2).

\section{Effect of $G$. bimaculatus water extracts on cell death of H460 cells}

Cell death is an important regulatory cellular mechanism. $\mathrm{H} 460$ cell death was induced by $\mathrm{G}$. bimaculatus water extracts (Fig. 3) and assessed by annexin V-FITC/PI staining. Cell death was detected by annexin V-FITC/PI with $500 \mu \mathrm{g} / \mathrm{mL}$ of $\mathrm{G}$. bimaculatus water extracts. These data support our findings that G. bimaculatus water extract may demonstrate anti-cancer effect in human NSCLC cells, without inducing cell death in healthy cells (data not shown).

\section{Effect of G. bimaculatus water extracts on caspase and poly(ADP-ribose) polymerase (PARP) pathways in $\mathbf{H 4 6 0}$ cells}

Cells undergo apoptosis due to extracellular signals, 'death factors', or by internal physical insults such as DNA damage or oxidative stress. Subsequently, two nonexclusive molecular pathways, the extrinsic and the intrinsic pathways, may be activated. Evading apoptosis is a hallmark of human cancer cells. Apoptotic cell death is induced by caspases and several regulatory factors with cancer formation resulting from insufficient caspase activation causing malfunction of apoptosis (Olsson and Zhivotovsky, 2011). Caspases are synthesized as inactive enzymes called procaspases, which are mostly considered inactive. Since caspases cleave at aspartate residues and procaspases are activated by cleavage at aspartate residues, caspases participate in a cascade of activation whereby one caspase activate other caspases in chain reactions. Therefore, regulation of apoptosis is controlled by both initiator and effector caspases. Effector caspases are produced in cells through proteolytic processing by initiator caspases. Caspase 8 is a known initiator caspase and is a key to the extrinsic pathway. Procaspase 8 molecules become activated by self-cleavage since procaspases have low enzymatic activity. This initiates a cascade of caspase activation, with the activated caspase activating executioner caspases. This cascade leads to cleavage of specific protein targets and results in apoptosis (Krelin et al., 2008). Caspase 9 is an initiator caspase key to the intrinsic pathway that is activated by aggregation. Caspase 9 begins a caspase cascade by cleaving and activating downstream caspases 3, 6, and 7. Activation of caspase 3 induces downstream cleavage of cytoplasmic or nuclear substrates, including PARP (Brauns et al., 2005), a marker of apoptosis. These downstream cleavage events show morphological features of apoptosis (Huppertz et al., 1999). PARP is a family of proteins involved in many cellular processes including DNA repair, apoptosis, genomic stability, and is inactivated by caspase cleavage.

Following treatment with $\mathrm{G}$. bimaculatus water extracts ( 250 or $500 \mu \mathrm{g} / \mathrm{mL})$ or LPS $(0.2 \mu \mathrm{g} / \mathrm{mL})$ for $24 \mathrm{~h}$ and suspension in a lysis buffer, expression of cleaved and uncleaved caspases 3, 8, and 9, and PARP in H460 cells were evaluated by western blot analysis. Extracts decreased levels of caspases 3, 8, and 9. With increased extract concentrations, expression levels of cleaved caspase were also significantly increased. However, G. bimaculatus water extracts did not affect expression of PARP, which

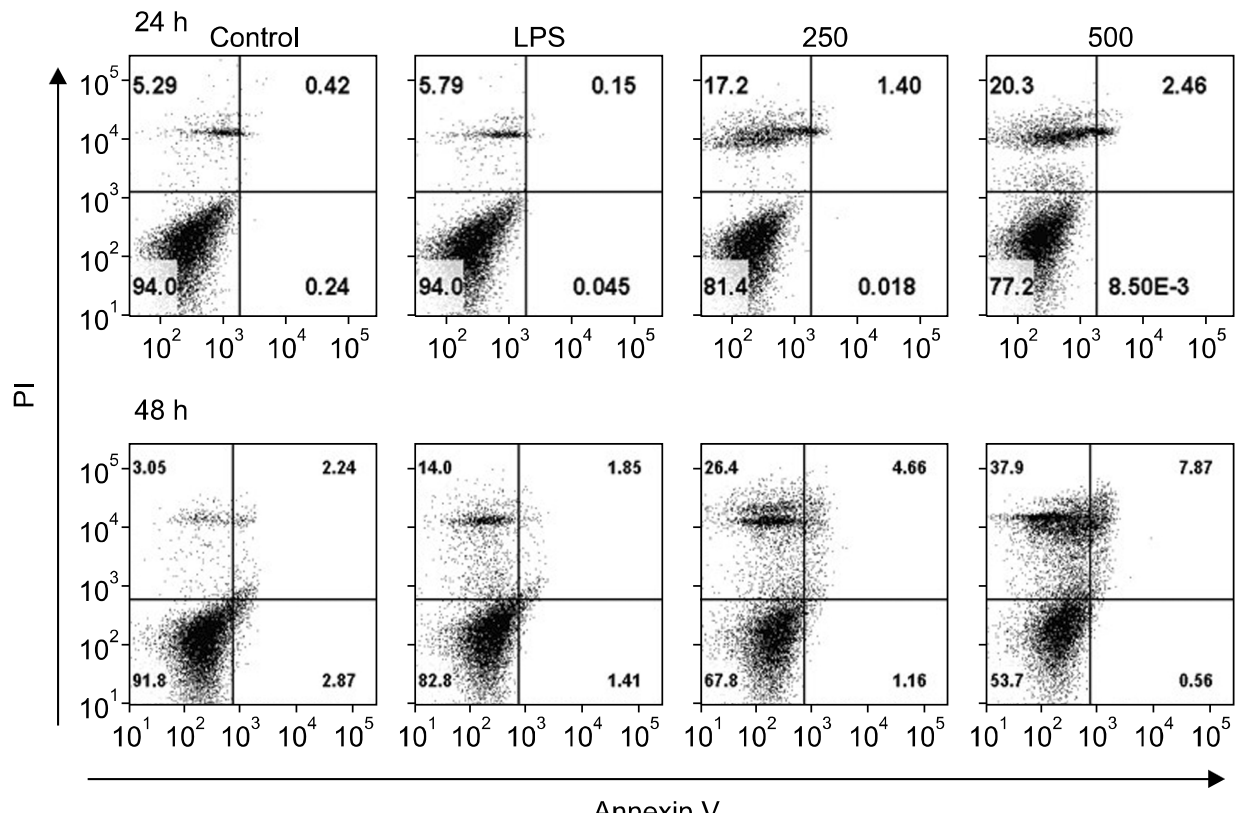

Fig. 3. Cell death induction by Gryllus bimaculatus water extracts. H460 cells were treated with lipopolysaccharide (LPS) $(100 \mathrm{ng} / \mathrm{mL})$ or G. bimaculatus water extracts ( 250 and $500 \mu \mathrm{g} / \mathrm{mL}$ ) for 24 or $48 \mathrm{~h}$. Cell death was determined using annexin V-fluorescein isothiocyanate and propidium iodide (PI) staining and detected by flow cytometry. 


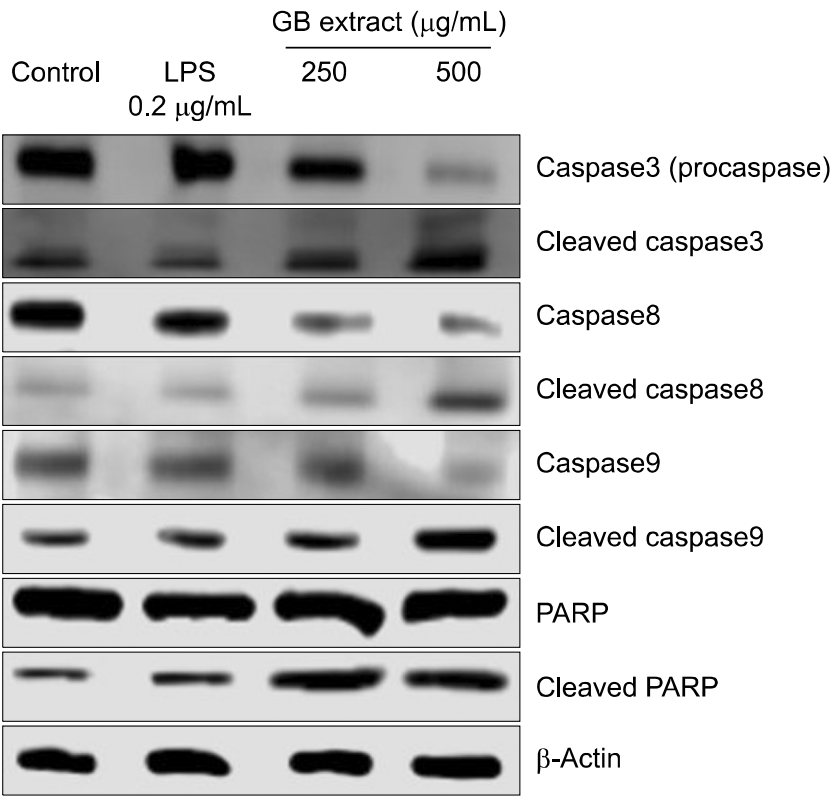

Fig. 4. Effects of Gryllus bimaculatus (GB) water extracts on protein expression of various caspases and poly(ADP-ribose) polymerase (PARP) in H460 human lung cancer cells. Cells were treated with lipopolysaccharide (LPS) $(0.2 \mu \mathrm{g} / \mathrm{mL})$ or GB water extracts ( 250 and $500 \mu \mathrm{g} / \mathrm{mL}$ ) for $24 \mathrm{~h}$, and lysed to extract proteins. Protein expression of various caspases and PARP was determined using western blot.

is specifically cleaved during the induction of apoptosis. These data suggests that G. bimaculatus water extracts induce apoptosis via caspase pathways in $\mathrm{H} 460$ human lung cancer cells (Fig. 4).

\section{Effect of $G$. bimaculatus water extracts on B-cell lymphoma 2 (Bcl-2) family pathways in $\mathbf{H 4 6 0}$ cells}

The two main pathways for apoptosis are the extrinsic receptor-mediated and intrinsic mitochondrial pathways. The Bcl-2 family of proteins modulates apoptosis in mitochondria, and includes proteins that either promote or inhibit apoptosis. Bcl-2 proteins control apoptosis by governing mitochondrial outer membrane permeabilization, which is a key step in the intrinsic pathway of apoptosis (Youle and Strasser, 2008). The ratio of pro- to anti-apoptotic subfamily members existing in cells can be altered by signaling pathways, dependent on cellular stress such as nutrients, DNA damage, and protein processing (Hetz and Glimcher, 2008). Once the executioners are activated, molecules come together to form pores in the outer mitochondrial membrane and stimulate mitochondrial outer membrane permeability (Nechushtan et al., 2001). Some $\mathrm{Bcl}-2$ family protein can release cytochrome $\mathrm{c}$ into the cytosol, which activates caspases 9 and 3, leading to apoptosis. The Bcl-2 family are characterized by Bcl-2 homology domains (Warren et al., 2019), which facilitate the interactions and their pro- or anti-apoptotic functions.

To elucidate the molecular pathways responsible for ap-

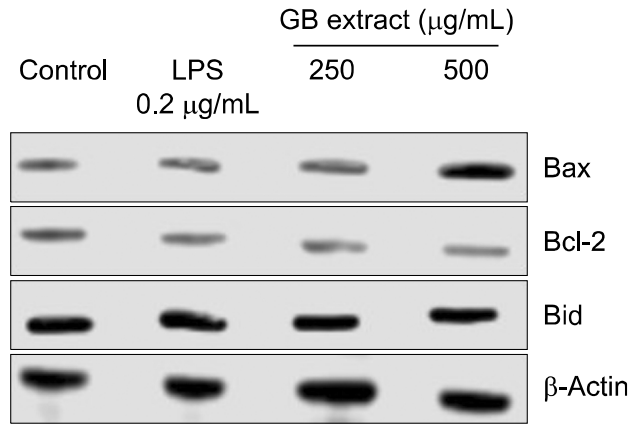

Fig. 5. Effects of Gryllus bimaculatus (GB) water extracts on expression of $\mathrm{Bcl}-2$ family proteins in $\mathrm{H} 460$ human lung cancer cells. Cells were treated with lipopolysaccharide (LPS) $(0.2 \mu \mathrm{g} /$ $\mathrm{mL}$ ) or $\mathrm{GB}$ water extracts ( 250 and $500 \mu \mathrm{g} / \mathrm{mL}$ ) for $24 \mathrm{~h}$, and lysed to extract proteins. Expression of various $\mathrm{Bcl}-2$ proteins was determined using western blot.

optotic effects on cancer cells, we analyzed the induction of apoptotic proteins. Cells were treated with G. bimaculatus water extracts at 250 or $500 \mu \mathrm{g} / \mathrm{mL}$ for $24 \mathrm{~h}$ and the levels of Bcl-2 family proteins were analyzed by western blot. Expression of Bax was increased in a dose-dependent manner and expression of Bcl-2 was decreased in H460 cells following treatment. Furthermore, expression of Bid did not differ from that of the control group. These data suggest that G. bimaculatus water extracts prevent induction of apoptosis by the Bcl-2 family pathway in H460 human lung cancer cells (Fig. 5).

To conclude, we showed that G. bimaculatus water extracts are safe and efficient natural materials that may have great potential in the treatment of lung cancer. $G$. bimaculatus water extracts induced apoptosis of lung cancer cells, and may be function via caspase and Bcl-2 family signaling pathways. However, the specific molecular mechanism needs to be further studied. This study was performed to explore novel and valuable uses of insect resources, important sources of natural compounds used in bio-industries. The results may be fundamental for further research into the use of different insects as natural resources.

\section{AUTHOR DISCLOSURE STATEMENT}

The authors declare no conflict of interest.

\section{REFERENCES}

Ahn MY, Han JW, Hwang JS, Yun EY, Lee BM. Anti-inflammatory effect of glycosaminoglycan derived from Gryllus bimaculatus (a type of cricket, insect) on adjuvant-treated chronic arthritis rat model. J Toxicol Environ Health A. 2014. 77:1332-1345.

Belluco S, Losasso C, Maggioletti M, Alonzi CC, Paoletti MG, Ricci A. Edible insects in a food safety and nutritional perspective: a critical review. Compr Rev Food Sci Food Saf. 2013. 12: 296-313. 
Boonsin P, Boonyarat C, Plekartoke K, Reubroycharoen P, Waiwut P. Antioxidant activity, $\beta$-amyloid aggregation inhibition, and neuroprotective effect of cricket (Gryllus bimaculatus) ethanol extract. Proceedings of the 6th International Conference on Biochemistry and Molecular Biology (BMB 2018). 2018 June 20-22. Rayong, Thailand. S1-P-28.

Brauns SC, Dealtry G, Milne P, Naudé R, Van de Venter M. Caspase-3 activation and induction of PARP cleavage by cyclic dipeptide cyclo(Phe-Pro) in HT-29 cells. Anticancer Res. 2005. 25:4197-4202.

Carmeliet P. VEGF as a key mediator of angiogenesis in cancer. Oncology. 2005. 69 Suppl 3:4-10.

Carney DN, Gazdar AF, Bepler G, Guccion JG, Marangos PJ, Moody TW, et al. Establishment and identification of small cell lung cancer cell lines having classic and variant features. Cancer Res. 1985. 45:2913-2923.

Cho HT, Sim KS, Kim Y, Chang MH, Kim T, Lee SH, et al. Anti-diabetic activity of edible insect Gryllus bimaculatus extracts in insulin-deficient diabetic mice. J Korean Soc Food Sci Nutr. 2019. 48:1165-1171.

Foster KA, Oster CG, Mayer MM, Avery ML, Audus KL. Characterization of the A549 cell line as a type II pulmonary epithelial cell model for drug metabolism. Exp Cell Res. 1998. 243:359366.

Giard DJ, Aaronson SA, Todaro GJ, Arnstein P, Kersey JH, Dosik $\mathrm{H}$, et al. In vitro cultivation of human tumors: establishment of cell lines derived from a series of solid tumors. J Natl Cancer Inst. 1973. 51:1417-1423.

Gonçalves M, Cappellari ÁR, dos Santos AA Jr, de Marchi FO, Macchi FS, Antunes KH, et al. Effect of LPS on the viability and proliferation of human oral and esophageal cancer cell lines. Braz Arch Biol Technol. 2016. 59:e16150485. https://doi.org/ 10.1590/1678-4324-2016150485

Gu JJ, Qiao KS, Sun P, Chen P, Li Q. Study of EGCG induced apoptosis in lung cancer cells by inhibiting PI3K/Akt signaling pathway. Eur Rev Med Pharmacol Sci. 2018. 22:4557-4563.

Hetz C, Glimcher L. The daily job of night killers: alternative roles of the BCL-2 family in organelle physiology. Trends Cell Biol. 2008. 18:38-44.

Huppertz B, Frank HG, Kaufmann P. The apoptosis cascademorphological and immunohistochemical methods for its visualization. Anat Embryol. 1999. 200:1-18.

Hwang BB, Chang MH, Lee JH, Heo W, Kim JK, Pan JH, et al. The edible insect Gryllus bimaculatus protects against gut-derived inflammatory responses and liver damage in mice after acute alcohol exposure. Nutrients. 2019. 11:857. https://doi.org/ 10.3390/nu11040857

Im AR, Yang WK, Park YC, Kim SH, Chae S. Hepatoprotective effects of insect extracts in an animal model of nonalcoholic fatty liver disease. Nutrients. 2018. 10:735. https://doi.org/10. 3390/nu10060735

Jang H, Kim M. Antidiabetic, anticholesterol, and antioxidant activity of Gryllus bimaculatus fermented by Bacillus and Lactobacillus strains. Appl Sci. 2021. 11:2090. https://doi.org/10.3390/ app11052090

Jeong T, Yu M, Heo H, Yang J, Jeong H, Lee J. Protective effect of Gryllus bimaculatus methanol extract on UVB-induced photoaging in human skin fibroblasts. J Korean Soc Food Cult. 2020.
35:478-482.

Krelin Y, Zhang L, Kang TB, Appel E, Kovalenko A, Wallach D. Caspase-8 deficiency facilitates cellular transformation in vitro. Cell Death Differ. 2008. 15:1350-1355.

Lee E, Kwon O. The effect of invasive cricket species, Gryllus bimaculatus on the survival of Korean cricket species, Teleogryllus emma. Korean J Ecol Environ. 2013. 46:67-74.

Lee S, Ahn KS, Ryu HY, Kim HJ, Lee JK, Cho MH, et al. Safety evaluation of cricket (Gryllus bimaculatus) extract in SpragueDawley rats. Int J Ind Entomol. 2016. 32:12-25.

Liu YZ, Wang YX, Jiang CL. Inflammation: the common pathway of stress-related diseases. Front Hum Neurosci. 2017. 11:316. https://doi.org/10.3389/fnhum.2017.00316

Mito T, Noji S. The two-spotted cricket Gryllus bimaculatus: an emerging model for developmental and regeneration studies. CSH Protoc. 2008. 2008:pdb.emo110. https://doi.org/10. 1101/pdb.emo110

Mitsudomi T, Viallet J, Mulshine JL, Linnoila RI, Minna JD, Gazdar AF. Mutations of ras genes distinguish a subset of non-smallcell lung cancer cell lines from small-cell lung cancer cell lines. Oncogene. 1991. 6:1353-1362.

Morishima A, Inagawa H. Clinical effects of orally administered lipopolysaccharide derived from Pantoea agglomerans on malignant tumors. Anticancer Res. 2016. 36:3747-3751.

Nechushtan A, Smith CL, Lamensdorf I, Yoon SH, Youle RJ. Bax and Bak coalesce into novel mitochondria-associated clusters during apoptosis. J Cell Biol. 2001. 153:1265-1276.

Olsson M, Zhivotovsky B. Caspases and cancer. Cell Death Differ. 2011. 18:1441-1449.

Park WJ, Han JS. Gryllus bimaculatus extract protects against lipopolysaccharide and palmitate-induced production of proinflammatory cytokines and inflammasome formation. Mol Med Rep. 2021. 23:206. https://doi.org/10.3892/mmr.2021.11845

Panov SZ. Molecular biology of the lung cancer. Radiol Oncol. 2005. 39:197-210.

Rumpold BA, Schlüter O. Insect-based protein sources and their potential for human consumption: nutritional composition and processing. Anim Front. 2015. 5:20-24.

Sameen AM, Jabir MS, Al-Ani MQ. Therapeutic combination of gold nanoparticles and LPS as cytotoxic and apoptosis inducer in breast cancer cells. AIP Conf Proc. 2020. 2213:020215. https://doi.org/10.1063/5.0000161

Seo DH, Hwang SY, Han J, Koh SK, Kim I, Ryu KS, et al. Immuneenhancing activity screening on extracts from two crickets, Gryllus bimaculatus and Teleogryllus emma. Entomol Res. 2004. 34:207-211.

Siegel RL, Miller KD, Jemal A. Cancer statistics, 2016. CA Cancer J Clin. 2016. 66:7-30.

Singh N, Baby D, Rajguru JP, Patil PB, Thakkannavar SS, Pujari VB. Inflammation and cancer. Ann Afr Med. 2019. 18:121-126.

van Huis A, Dicke M, van Loon JJA. Insects to feed the world. J Insects Food Feed. 2015. 1:3-5.

Warren CFA, Wong-Brown MW, Bowden NA. BCL-2 family isoforms in apoptosis and cancer. Cell Death Dis. 2019. 10:177. https://doi.org/10.1038/s41419-019-1407-6

Youle RJ, Strasser A. The BCL-2 protein family: opposing activities that mediate cell death. Nat Rev Mol Cell Biol. 2008. 9:4759. 